\title{
Evaluation of Mercury Concentrations in Groundwater Samples of Coal Field Using a Matrix-less Cloud Point Extraction Procedure Prior to Analysis by Cold Vapor Atomic Absorption Spectrometry
}

\author{
Jamshed Ali ${ }^{a, b}$, Tasneem G. Kazi ${ }^{b}$, Mustafa Tuzen ${ }^{a, c, *}$, Hassan I. Afridi ${ }^{b}$, and Naeemullah ${ }^{a, b}$ \\ ${ }^{a}$ Gaziosmanpasa University, Faculty of Science and Arts, Chemistry Department, 60250 Tokat, Turkey \\ b National Centre of Excellence in Analytical Chemistry University of Sindh, Jamshoro 76080, Pakistan \\ ${ }^{c}$ King Fahd University of Petroleum and Minerals, Research Institute, Center for Environment and Water, \\ Dhahran 31261, Saudi Arabia
}

\begin{abstract}
A novel matrix-less cloud point extraction (ML-CPE) procedure was developed for the determination of mercury $(\mathrm{Hg})$ in groundwater samples collected from the Thar coalfield, Pakistan. For preconcentration of $\mathrm{Hg}$, a complexing reagent, diethyldithiophosphate (DEDTP) was selected. Various parameters such as temperature, time, $\mathrm{pH}$, and amount of complexing reagent and concentration of surfactant concentrations were studied in order to find the best conditions for the enrichment of mercury in water samples. In the proposed method, the Hg-DEDTP was subsequently entrapped in the nonionic surfactant, Triton $\mathrm{X}-114$. Then, Hg was backextracted into the matrix-less aqueous phase and determined by cold vapor atomic absorption
\end{abstract}

spectrometry (CVAAS). At opti mized experimental parameters, the limit of detection and the enhancement factor were found to be $7.5 \mathrm{ng} / \mathrm{L}$ and $22.8 \mathrm{ng} / \mathrm{L}$, respectively. The relative standard deviation (RSD) for six replicates at $5 \mu \mathrm{g} / \mathrm{L}$ of $\mathrm{Hg}$ was $4.6 \%$, which indicates that the developed method is highly precise and repeatable. The accuracy of the method was verified by spiking the known concentration of the standards in a real sample. No significant difference $(p>0.05)$ was observed between the experimental results and the added analyte. The developed ML-CPE method was successfully applied for the preconcentration and determination of $\mathrm{Hg}$ in groundwater samples. The levels of $\mathrm{Hg}$ in the groundwater samples of the Thar coal field was in the range of $1.8-3.23 \mu \mathrm{g} / \mathrm{L}$.

\section{INTRODUCTION}

The Pakistan coal mining sector has many environmental challenges such as degradation of groundwater quality, emission of nitrogen oxide, sulfur oxide, and particulate matter from various mining activities $(1,2)$. In the mining sector, acid mine drainage and metals leaching into groundwater can deteriorate the water quality,

\footnotetext{
*Corresponding author.

E-mai: mustafa.tuzen@gop.edu.tr

Tel: + 903562521616

Fax: + 903562521585
}

which creates health risks to aquatic and human life $(3,4)$. Water pollution caused by mercury $(\mathrm{Hg})$ contributes to biodiversity loss, environmental degradation, and human health hazards (5-8). Mercury is a non-degradable toxic metal which can accumulate in the human body causing damage to the nervous system and internal organs (9-10). High $\mathrm{Hg}$ concentrations cause toxicity and environmental risk (11) and enter into the environment due to the combustion of coal for power generation, waste burning, and other energy sources (12-
14). The high exposure of $\mathrm{Hg}$ in organic form caused the Minamata disease, a neurological syndrome, which was first observed in Minamata City, Japan, and continued to be monitored from 1932 to 1968. In 1956, Japan reported that 1043 persons had died and 2252 persons were suffering from this disease due to the elevated $\mathrm{Hg}$ levels in fish (15).

A coal mine can be operated in various ways such as open pit, underground methods, surface stripping, and hydraulic leaching (16). Mining generates a large amount of waste (17) which can enter into the groundwater from mine discharge, runoff, chemical weathering of rocks and soils and wet and dry fallout from atmospheric particulate matter (18). One of the routes in which $\mathrm{Hg}$ enters into the human body is drinking water (19). Hence, control of $\mathrm{Hg}$ is becoming increasingly important, especially in water sources (20). According to WHO and the European Union Guidelines for Drinking water, the permissible limit of $\mathrm{Hg}$ in water is $1.0 \mu \mathrm{g} / \mathrm{L}$, with a mean value of $2.46 \mu \mathrm{g} / \mathrm{L} \mathrm{Hg}$ (21-23).

Due to the toxicological impact of $\mathrm{Hg}$ concentrations in the environment, it has encouraged the development of very sensitive methodologies for its determination by techniques such as cold vapor atomic absorption spectrometry (CVAAS). However, the presence of mercury in groundwater is mostly at very low concentrations and its determination requires enrichment 
steps. Among the different preconcentration methods, cloud point extraction is an interesting alternative because it produces high enrichment efficiencies and concentration factors, and uses lowcost, non-toxic reagents (24-29).

CPE is based on the hydrophobic interaction between the organometallic complex and the surfactant, whereas the other hydrophobic species can be extracted into the surfactant-rich phase and may interfere in the analysis of the elements of interest. The drawbacks of traditional CPE are overcome by a modified matrix-less cloud point extraction. In the proposed ML-CPE methodology of the present study, the resulting $\mathrm{Hg}$ complex was entrapped in a nonionic surfactant and back-extracted in aqueous solution to minimize the adverse effects of the surfactant.

\section{Thar Coal Field}

The Thar coalfield is located in the Thar Desert, situated at the south-eastern parts of Sindh province, Pakistan, and is the largest lignite coal reserve in the world (30). It is the hottest area in the country with temperatures ranging from $28^{\circ} \mathrm{C}$ to $48^{\circ} \mathrm{C}$ in the summer and varies from $9{ }^{\circ} \mathrm{C}$ to $24^{\circ} \mathrm{C}$ in the winter. Limited rainfall in the Thar province varies from 200 to $250 \mathrm{~mm}$ per year. The population of the Tharparkar province of Sindh has limited access to fresh drinking water and rely on stored rainwater and groundwater.

\section{EXPERIMENTAL}

\section{Instrumentation}

A double-beam model AAnalyst ${ }^{\mathrm{TM}}$ 700 atomic absorption spectrophotometer, coupled with an MHS-15 chemical vapor generation system, was used (PerkinElmer, Inc., Shelton, CT, USA). A single-element hollow cathode $\mathrm{Hg}$ lamp operated at $5 \mathrm{~mA}$ was used as the energy source.
The Hg signal was isolated at 253.7 nm with a spectral bandwidth of $0.7 \mathrm{~nm}$. WinLab ${ }^{\mathrm{TM}} 32$ software (PerkinElmer, Inc.) was used to process and calculate the analytical data. The centrifuge used was a model ROWKA Laboratoryjna, type WE-1, No. 6933 (Mechanika Phecyzyjna, Poland). The incubation time and temperature were measured by a programmable SC-121TH ultrasonic water bath (Sonicor, Deer Park, NY, USA), with a temperate range from $0{ }^{\circ} \mathrm{C}$ to $80{ }^{\circ} \mathrm{C}$ and a frequency of $35 \mathrm{kHz}$. The composite samples of groundwater were mixed with a mechanical shaker (220/60 Hz, Gallankamp, Germany). The $\mathrm{pH}$ of the groundwater was maintained according to the experimental requirements using a model Ecoscan Ion 6 pH meter (Kuala Lumpur, Malaysia). The programmable microwave oven (Osaka, Japan) was used to preconcentrate the water samples. The instrumental and operating conditions are listed in Table I.

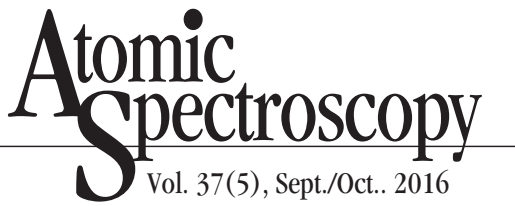

\author{
Reagents, Solutions, and \\ Glassware
}

Ultrapure water obtained from a Milli-Q ${ }^{\circledR}$ water system (ELGA Laboratory, Bucks, UK) was used throughout the experimental work. A working standard solution was prepared for calibration from $\mathrm{Hg}$ stock standard solution (1000 $\mathrm{mg} / \mathrm{kg}$, Fluka Kamica, Buchs, Switzerland). The surfactant Triton ${ }^{\circledR}$ X-114 (tert-octylphenoxypoly(ethoxyethanol) (SigmaAldrich, St. Louis, MO, USA), the complexing reagent DEDTP (Aldrich, Milwaukee, WI, USA), and $\mathrm{NaBH}_{4}$ as the reducing agent (Aldrich, Milwaukee, WI, USA) were used. The high quality grade antifoaming agent of $\mathrm{KMnO}_{4}$ (Sigma) was used for Hg determination (see Table I). All glassware and polyethylene bottles were thoroughly washed with water, then soaked overnight in $5.0 \mathrm{~mol} / \mathrm{L}$ $\mathrm{HNO}_{3}$ and finally thoroughly rinsed with Milli-Q ${ }^{\circledR}$ water (Millipore Corporation, USA) to remove the remaining residual acid content on the inside walls of the glassware.
TABLE I

Instrumental and Operating Parameters for Hg Determination by CV-AAS

\begin{tabular}{|c|c|}
\hline Instrumentation & AAnalyst ${ }^{\mathrm{TM}} 700 \mathrm{AAS}$ \\
\hline Lamp current & $5.0 \mathrm{~mA}$ \\
\hline Analytical wavelength & $253.7 \mathrm{~nm}$ \\
\hline Slit-width and height & $0.7 \mathrm{~nm}$, Low \\
\hline Radiation source & HCL \\
\hline QTA heating & No flame required \\
\hline Characteristic mass & $4.68 \mathrm{ng}$ \\
\hline Characteristic concentration & $0.468 \mu \mathrm{g} / \mathrm{L}$ \\
\hline Argon carrier gas (99.99\%) & $200 \mathrm{~mL} / \mathrm{min}$ \\
\hline Background correction & $\mathrm{D}_{2}$ Lamp \\
\hline Diluent/Carrier solution & $1.5 \% \mathrm{HNO}_{3}(\mathrm{v} / \mathrm{v})$ \\
\hline Reducing agent & $3 \% \mathrm{NaBH}_{4}$ in $1 \% \mathrm{NaOH}(\mathrm{w} / \mathrm{v})$ \\
\hline Stabilizing/antifoaming agent & $5 \% \mathrm{KMnO}_{4}(\mathrm{w} / \mathrm{v})$ \\
\hline Pre-reaction purge time & $30 \mathrm{~s}$ \\
\hline Reaction time & $5.0 \mathrm{~s}$ \\
\hline Post-reaction purge time & $40 \mathrm{~s}$ \\
\hline Sample volume & $10.0 \mathrm{~mL}$ \\
\hline
\end{tabular}




\section{Collection of Samples}

Groundwater samples from the Thar coal field were collected using the standard method (31-32) and with legal permission and assistance provided by the Sindh coal authority. The high power compressor was operated for withdrawing groundwater for drinking. All other activities of mining at the time of sampling in 2014 were continued. Twenty samples were collected and stored in washed polyethylene bottles and brought to the laboratory on same day to avoid contamination. The samples were filtered with Whatman $0.45 \mu \mathrm{m}$ filter paper by using a vacuum pump and kept at $4^{\circ} \mathrm{C}$ until determination of $\mathrm{Hg}(33,34)$.

\section{ML-CPE Procedure}

The ML-CPE procedure consists of two steps. First, $10.0 \mathrm{~mL}$ groundwater samples and standard solutions containing $0.5-10 \mu \mathrm{g} / \mathrm{L} \mathrm{Hg}$ were added into glass tubes with a stopper (20-mL capacity). Then $0.5 \mathrm{~mL}$ of DEDTP (0.1-0.5\%) and $2.0 \mathrm{~mL}$ of Triton X-114 surfactant (0.1-1.0\%) were added. The $\mathrm{pH}$ was maintained in the range of $1.0-4.0$ by adding $0.10 \mathrm{~mol} / \mathrm{L}$ of
$\mathrm{HNO}_{3} / \mathrm{NaOH}$ in acetate buffer. The resulting solution was kept at $45^{\circ} \mathrm{C}$ for 10 minutes. Separation of the two phases was achieved by centrifugation at $4000 \mathrm{rpm}$ for $10 \mathrm{~min}$ utes. The content of the tubes was placed into a container of ice to enhance the viscosity of the surfactant-enriched phase with the targeted $\mathrm{Hg}$ analyte, and then the remaining aqueous solution was discarded.

For the second step, the surfactant-rich phase containing the $\mathrm{Hg}$ complex was treated with $2.0 \mathrm{~mL}$ of 0.5-2.0 mol/L NaOH to leach out the $\mathrm{Hg}$ metal into the alkaline aqueous solution. Then the solutions were placed into a thermostatic bath at $45^{\circ} \mathrm{C}$ for 10 minutes and centrifuged to separate the two phases. After ML-CPE, the supernatant was introduced into the CVAAS for the determination of $\mathrm{Hg}$. The same procedure was applied for the preparation of the blanks.

\section{RESULTS AND DISCUSSION}

\section{Optimization of ML-CPE Method}

\section{Effect of $p H$}

The $\mathrm{pH}$ plays an important role on the extraction efficiency of the
ML-CPE method and also affects the overall formation of the complex between the target analyte and the complexing reagent. The effect of $\mathrm{pH}$ on the extraction efficiency of $\mathrm{Hg}$ was studied in the range of 1.0-4.0, while the other parameters were kept at their optimum levels. The complexing reagent DEDTP is selective for the formation of the complex with $\mathrm{Hg}$ at $\mathrm{pH} \mathrm{1.5,} \mathrm{while}$ at $\mathrm{pH}>2.5$ the extraction efficiency of $\mathrm{Hg}$ decreased as is shown in Figure 1 . Therefore, a $\mathrm{pH}$ of 1.5 was selected as optimal for the proposed method.

\section{Effect of DEDTP Concentration}

DEDTP was selected as the optimal complexing agent due to the highly hydrophobic nature of the complexes with metals/metalloid. The extraction efficiency of $\mathrm{Hg}$ from the groundwater samples with a DEDTP concentration ranging from $0.1-0.5 \%$ (w/v) was used. Maximum recovery of $\mathrm{Hg}$ was observed up to a DEDTP concentration of $0.30 \%(\mathrm{w} / \mathrm{v})$, while a further increase had no effect on the recovery as is shown in Figure 2. Thus, $0.30 \%$ DEDTP concentration was selected for the effective quantification of $\mathrm{Hg}$ in groundwater samples.

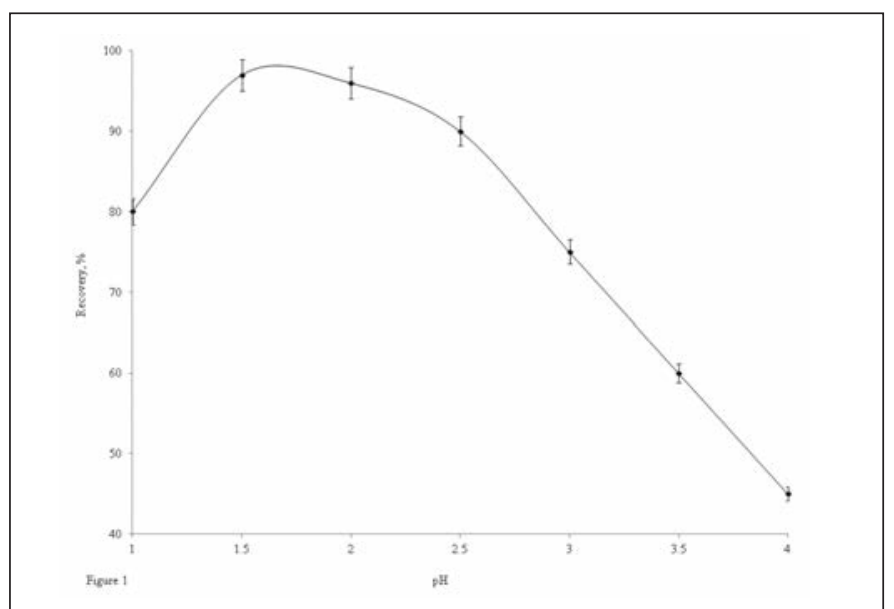

Fig. 1. Effect of $\mathrm{pH}$ on pre-concentration of $\mathrm{Hg}$ by $\mathrm{ML}-\mathrm{CPE}$ method using $2.0 \mu \mathrm{g} / \mathrm{L} \mathrm{Hg;} \mathrm{DEDTP,} 0.30 \%$ (w/v); Triton $X-114,0.25 \%(v / v)$; equilibration temperature $45^{\circ} \mathrm{C}$; and time 14 minutes.

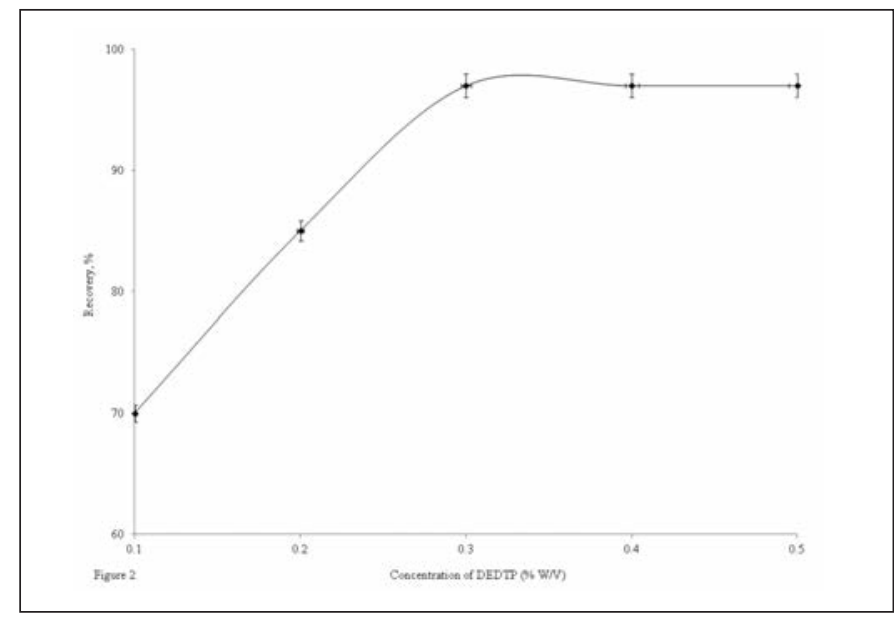

Fig. 2. Effect of DEDTP concentration on pre-concentration of $\mathrm{Hg}$ by ML-CPE method using $2.0 \mu \mathrm{g} / \mathrm{L} \mathrm{Hg}$; $\mathrm{pH} \mathrm{1.5;} \mathrm{Triton}$ $X-114,0.25 \%(v / v)$; equilibration temperature $45^{\circ} \mathrm{C}$, and time 14 minutes. 


\section{Effect of Triton X-114 Concentra- tion}

Triton $\mathrm{X}-114$ is the best option in ML-CPE, because it is a non-ionic surfactant with a low cloud point temperature and enables phasepartitioning of hydrophilic solutions from amphiphilic solutions. The effect of surfactant concentration on the preconcentration of $\mathrm{Hg}$ was investigated and optimized in the range of $0.1-0.45 \%$. The effect of Triton X-114 concentration on the \%recovery of $\mathrm{Hg}$ is shown in Figure 3. Optimum concentration of Triton $\mathrm{X}-114$ was found to be $0.25 \%$ for optimum recovery of $\mathrm{Hg}$. Therefore, $0.25 \%$ of Triton X-114 concentration was selected for the subsequent extraction of $\mathrm{Hg}$ in the ML-CPE procedures.

\section{Effect of Temperature and Incubation Time}

The extraction efficiency of $\mathrm{Hg}$ could be achieved when the MLCPE process is carried out at the equilibration temperature above the cloud point temperature of the surfactant (Triton X-114). In the current work, the equilibrium temperature was studied in the range of $20-75^{\circ} \mathrm{C}$ by using the ultrasonic water bath. It was observed that $45^{\circ} \mathrm{C}$ was adequate for the $\mathrm{Hg}$ complex. Time also plays an important role for the extraction of $\mathrm{Hg}$ from groundwater and therefore, the study of equilibrium time was performed in the range of 4-25 minutes. An equilibration time of 14 minutes was chosen for the quantitative extraction of $\mathrm{Hg}$. The best and effective incubation temperature and time in the second step of the ML-CPE procedure was found to be $45^{\circ} \mathrm{C}$ and 14 minutes, respectively.

\section{Effect of Back-extraction of Reagents}

In the second step of the ML-CPE procedure, the effect of backextraction with the basic reagents was studied. For this purpose, 0.5-2.0 mol/L NaOH/HCl was used to back-extract $\mathrm{Hg}$ into the aqueous phase from the hydrophobic complexes trapped in the micelle solution (Triton X-114). Maximum Hg recovery was obtained with 1.0 $\mathrm{mol} / \mathrm{L}$ of $\mathrm{NaOH}$, while a $10-20 \%$ lower recovery of $\mathrm{Hg}$ was obtained with $1.0 \mathrm{~mol} / \mathrm{L} \mathrm{HCl}$. Therefore, 1.0 $\mathrm{mol} / \mathrm{L}$ of $\mathrm{NaOH}$ solution was used to back-extract $\mathrm{Hg}$ into the aqueous solution.

\section{Effect of Interfering Ions}

The advantages of the proposed ML-CPE method were investigated.

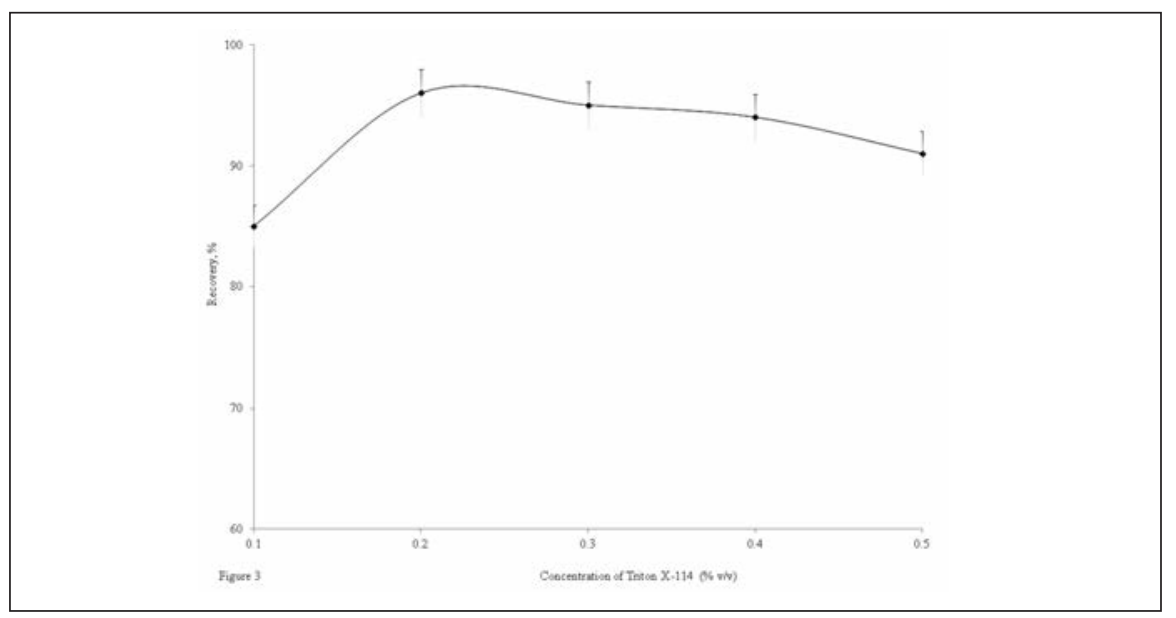

Fig. 3. Effect of Triton X-114 concentration on pre-concentration of $\mathrm{Hg}$ by ML-CPE method using $2.0 \mu \mathrm{g} / \mathrm{L} \mathrm{Hg} ; \mathrm{pH} 1.5 ; 0.25 \%(v / v)$; equilibration temperature $45^{\circ} \mathrm{C}$, and time 14 minutes.

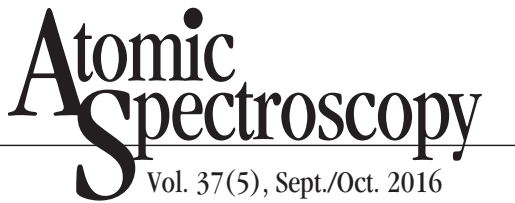

A series of solutions of $15.0 \mathrm{~mL}$ containing $50 \mu \mathrm{g} / \mathrm{L}$ of $\mathrm{Hg}$ and different concentrations of interfering ions $\left(\mathrm{ClO}_{4}^{-}, \mathrm{PO}_{4}{ }^{3-}, \mathrm{CH}_{3} \mathrm{COO}^{-}, \mathrm{NO}_{3}{ }^{-}\right.$, $\mathrm{SO}_{4}^{2-}, \mathrm{K}^{+}, \mathrm{Na}^{+}, \mathrm{Mg}^{2+}, \mathrm{Ca}^{2+}, \mathrm{Ba}^{2+}$, $\mathrm{Zn}^{2+}, \mathrm{Al}^{3+}$, and $\mathrm{Fe}^{3+}$ ) were subjected to the ML-CPE procedure at optimized values of the parameters. It was found that for $\mathrm{ClO}_{4}^{-}, \mathrm{PO}_{4}^{3-}$, $\mathrm{CH}_{3} \mathrm{COO}^{-}, \mathrm{NO}_{3}{ }^{-}, \mathrm{SO}_{4}{ }^{2-}, \mathrm{K}^{+}$, and $\mathrm{Na}^{+}$, the metal to interference ratio was 1:3500, and for $\mathrm{Mg}^{2+}, \mathrm{Ca}^{2+}$, and $\mathrm{Ba}^{2+}$ it was $1: 1200$, while for $\mathrm{Zn}^{2+}, \mathrm{Al}^{3+}$, and $\mathrm{Fe}^{3+}$ the ratio was 1:600. It was observed that matrix components such as alkali and alkaline earth metals have much less effect on the selectivity of the proposed method. This might be due to the fact that these metals do not form stable complexes with DEDTP. Thus, it can be stated that the proposed method can be selectively used as a separation tool for $\mathrm{Hg}$ determination at given tolerance limits of the coexisting ions.

\section{Analytical Capability of ML-CPE}

A linear calibration graph was achieved by using working standard solutions of $\mathrm{Hg}$ in the range of $0.5-10 \mu \mathrm{g} / \mathrm{L}$. The analytical sensitivity was obtained by least squares regression analysis of the calibration graphs based on peak area measurements. The equation used for the calibration graph was:

$$
\mathrm{Y}=0.1003 \mathrm{Hg}+0.0068
$$

where $\mathrm{Y}$ is the integrated value of the peak area. The limit of detection (LOD) was defined as LOD = $3 \times \mathrm{SD} / \mathrm{m}$, where SD is the standard deviation corresponding to 10 blank injections and $\mathrm{m}$ is the slope of the calibration graph. The LOD was found to be $7.5 \mathrm{ng} / \mathrm{L}$ and is listed in Table II. The enrichment factor (EF) was estimated from the ratio of the slope of the calibration curves with and without ML-CPE, and the observed value of the enrichment factor was 22.8. The standard addition method was used to assess the accuracy and validity of the proposed ML-CPE method of 
$\mathrm{Hg}$ at two concentration levels in real groundwater samples (see Table III). Based on the developed ML-CPE/CVAAS method, a recovery of $>98 \%$ was obtained which confirms the capability and validity of the proposed method. The high enrichment factor and the low LOD of the ML-CPE method suggest that the method is very sensitive and selective for the measurement of $\mathrm{Hg}$ in groundwater samples from the Thar coalfield. The proposed method was satisfactory and comparable to other reported methods (36-39) as is shown in Table IV.

\section{Applications of the Proposed Method}

The proposed extraction method was successfully applied for the determination of $\mathrm{Hg}$ in groundwater samples of the Thar coalfield, Pakistan. The Tharparkar ground-

TABLE II

Analytical Capability of ML-CPE Method

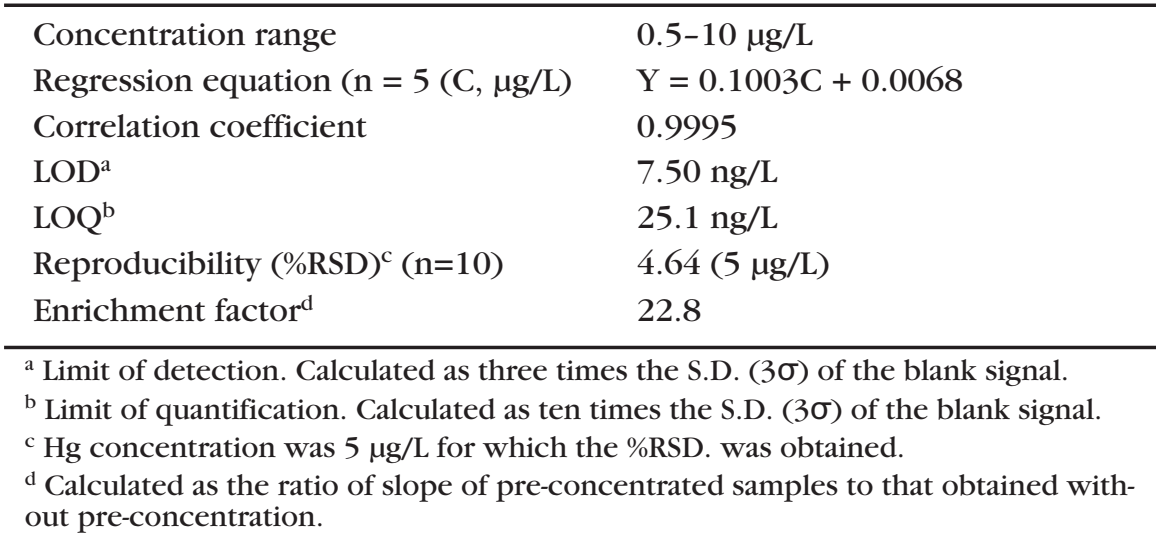

TABLE III

Hg Determination in Real Groundwater Samples by ML-CPE*

\begin{tabular}{lccc}
\hline Samples & Added $(\mu \mathrm{g} / \mathrm{L})$ & Measured $(\mu \mathrm{g} / \mathrm{L})$ & Recovery $(\%)$ \\
\hline Groundwater & 0 & $2.46 \pm 0.78$ & - \\
& 2.0 & $4.44 \pm 3.12$ & 99.6 \\
& 4.0 & $6.40 \pm 3.98$ & 99.1 \\
\hline
\end{tabular}

${ }^{*}$ Mean \pm S.D. $(\mathrm{n}=3)$.

TABLE IV

Comparative Data of Proposed ML-CPE Method for Hg Determination With Conventional CPE Methods

\begin{tabular}{lllcll}
\hline $\begin{array}{c}\text { Pre-concentration } \\
\text { Method }\end{array}$ & $\begin{array}{c}\text { Concentration } \\
\text { Range }(\mu \mathrm{g} / \mathrm{L})\end{array}$ & $\begin{array}{c}\text { RSD } \\
(\%)\end{array}$ & $\begin{array}{c}\text { Enrichment } \\
\text { Factor }\end{array}$ & $\begin{array}{c}\text { LOD } \\
(\mu \mathrm{g} / \mathrm{L})\end{array}$ & Ref. \\
\hline CPE/GFAAS & - & 4.0 & 22 & 0.01 & $(35)$ \\
CPE/P/ FIA & $50-500$ & 4.8 & 6 & 0.014 & $(36)$ \\
CPE/CVAAS & - & - & 10 & 0.4 & $(37)$ \\
CPE/CVAAS & $10-400$ & - & - & 3.0 & $(38)$ \\
CPE/CVAAS & - & 4.6 & 12 & 0.117 & $(39)$ \\
ML-CPE/CVAAS & $0.5-10$ & 4.64 & 22.8 & 0.0075 & Present \\
& & & & & Study \\
\hline
\end{tabular}

water is one of the main sources of drinking water for the local population due to the lack of fresh and pure drinking water throughout the Thar region. The pollution generated from coal mines due to underground gasification results in minerals being dissolved when they come in contact with water. The leaching of $\mathrm{Hg}$ due to the use of coal for electricity generation by underground coal gasification may cause the $\mathrm{Hg}$ contamination of the groundwater. Since the local population of the Thar area uses groundwater for drinking, most of which is probably collected from underground shallow water sources or well water, it poses a considerable risk of $\mathrm{Hg}$ contamination. The results of this study show that the mean value of $\mathrm{Hg}$ in the groundwater samples of the Thar coalfield was $2.46 \mu \mathrm{g} / \mathrm{L}$ (see Table III), a value which is above the approved WHO and European Union level of $1.0 \mu \mathrm{g} / \mathrm{L}$.

\section{CONCLUSION}

In this work, a matrix-less cloud point extraction (ML-CPE) procedure is introduced to eliminate matrix effects in the determination of trace levels of $\mathrm{Hg}$ in groundwater samples of the Thar coal fields in Pakistan by cold vapor atomic absorption spectrometry. Compared with conventional CPE, the proposed method has extensive application in sample pre-concentration and qualitative analysis of $\mathrm{Hg}$ in complex matrices. The proposed ML-CPE method significantly eliminates interference from surfactant, foreign ions, and matrices. With these advantages it offers an extensive application for the preconcentration step to increase the sensitivity of the spectroscopic detection techniques in complex matrixes. The analytical features such as enhancement factor (EF), limit of detection (LOD), and accuracy of the method were satisfactory and comparable to other 
reported methods. The developed ML-CPE method provides useful information for the quantitative determination of $\mathrm{Hg}$ in different environmental samples.

\section{ACKNOWLEDGMENT}

Jamshed Ali and Naeemullah would like to acknowledge the TUBITAK-2216 Research Fellowship Programme for International Researcher of the Scientific and Technological Research Council of Turkey, and give thanks for their financial support and sponsoring of this study. The authors also thank Gaziosmanpasa University for providing the required facilities.

$\overline{\text { Received February 2, } 2016 .}$

\section{REFERENCES}

1. T. R. Hawkins, B. Singh, G. M.Bettez and A. H. Strømman, J. of Industrial Ecology 17, 53 (2013).

2. V. Nebot and R. Berlanga, Knowledge-Based Systems 25, 51(2012).

3. C. Hadjimichalis, European Urban and Regional Studies 18, 254 (2011).

4. J. Prno and D. S. Slocombe, Resources Policy 37, 346 (2012).

5. G. Dević, S. Sakan and D. Đorđević, Environ. Sci. and Poll. Re. 23, 282 (2016).

6. K. A. Kidd, P. J. Blanchfield, K. H. Mills, V. P. Palace, R. E. Evans, J. M. Lazorchak and R. W. Flick, Proceedings of the National Acad. of Sci.104, 8897 (2007).

7. R. Buzier, M.H.Vuillemin, C. M. Meriadec, O. Rousselot and J.M. Mouchel, Chemo. 65, 2419 (2006).

8. S. Chatrchyan, V. Khachatryan, A. Sirunyan, A. Tumasyan, W. Adam, T. Bergauer, M. Dragicevic, J. Erö, C. Fabjan and M. Friedl, Phys. Rev. D.89, 09 (2014).

9. Z. Li and Z. Yan, Atmos. Oceanic Sci. Lett. 2, 237 (2009).

10. V. K. Nandula, D. H. Poston, K. N. Reddy and $\mathrm{K}$. Whiting, Internatl.
J. of Agronomy 2009, 07 (2009).

11. I. M. Dittert, T. A. Maranhão, D. L. Borges, M. A. Vieira, B. Welz and A. J. Curtius, Talanta 72, 1786 (2007).

12. J. Falandysz, A. Frankowska and A. Mazur, J. of Environ.Sci. and Health, Part A, 42, 2089 (2007).

13. W. F. Fitzgerald, C. H. Lamborg and C. R. Hammerschmidt, Chem. Rev. 107, 641 (2007).

14. T. J. Reilly, K. L. Smalling, J. L. Orlando and K. M. Kuivila, Chemo. 89, 228 (2012)

15. Q. Wang, D. Kim, D. D. Dionysiou, G. A. Sorial and D. Timberlake, Environ.Poll. 131, 323 (2004).

16. M. Pagel, V. Barbin, P. Blanc and D. Ohnenstetter, Cathodoluminescence in Geosciences, Springer Science \& Business Media (2013).

17. B. W. Ang, Energy Policy 33, 867 (2005).

18. R. G. Ohye, L. A. Sleeper, L. Mahony, J. W. Newburger, G. D. Pearson, M. Lu, C. S. Goldberg, S. Tabbutt, P. C. Frommelt and N. S. Ghanayem, New England J. of Medicine 362, 1980 (2010).

19. M. O. Angelidis and M. Aloupi, Marine Poll. Bull. 40, 77 (2000).

20. K. Sekabira, H. O. Origa, T. Basamba, G. Mutumba and E. Kakudidi, Inter. J. of Environ. Sci. \& Tech. 7, 435 (2010).

21. C. C. Ogueke, C. I. Owuamanam and J. I. Ezekiel, Amer. J. of Food Sci. and Nutr. 1, 1 (2014)

22. A. Papaioannou, S. Morin, A. M. Cheung, S. Atkinson, J. P. Brown, S. Feldman, D. A. Hanley, A. Hodsman, S. A. Jamal and S. M. Kaiser, Cana. Med. Asso. J. 182, 1864 (2010).

23. R. Srivastava, Cen. for Environ. Poll. Moni. and Miti. Lucknow, India. Submission to UNEP (August 2003).

24. D. L. G. Borges, M. A. M. S. da Veiga, V. L. A. Frescura, B. Welz and A. J. Curtius, J. of Anal. At. Spectrom. 18, 501 (2003).

25. M. Tuzen, I. Karaman, D. Citak and M. Soylak, Food and Chem. Toxico. 47, 1648 (2009).

\section{Atomic Apectroscopy 1 Vol. 37(5), Sept./Oct. 2016

26. M. S. Arain, T. G. Kazi, H. I. Afridi, S. A. Arain, J. Ali, N. Ullah, S. S. Arain, A. H. Panhwar and B. Shanker, J. Anal. At. Spectrom. 29, 2349 (2014).

27. D. P. Torres, M. A. Vieira, A. S. Ribeiro and A. J. Curtius, J. of Anal. At. Spectrom. 20, 289 (2005).

28. F. Bell, S. Bullock, T. Hälbich and P. Lindsay, Internatl. J. of Coal Geology 45, 195(2005).

29. D. Vermeulen and B. Usher, Water SA 35, 379 (2009).

30. J. Ali, T. G. Kazi, J. A. Baig, H. I. Afridi, M. S. Arain, N. Ullah, K. D. Brahman, S. S. Arain and A. H. Panhwar, Environ. Sci. and Poll. Review 1 (2015).

31. A. P. H. Association, Standard Methods for the Examination of Water and Wastewater, 20th Edition, APHA, Washington, DC, USA (2005).

32. World Health Organization (WHO), Guidelines for Drinking Water Quality, First addendum to volume 1, Recommendations (2006).

33. T. G. Kazi, M. B. Arain, J. A. Baig, M. K. Jamali, H. I. Afridi, N. Jalbani, R. A. Sarfraz, A. Q. Shah and A. Niaz, Sci. of the Total Environ. 407, 1019 (2009).

34. L. Yost, R. Schoof and R. Aucoin, Human and Ecological Risk Assessment: An Inter. J. 4, 137 (1998).

35. Z. Gong, X. Lu, M. Ma, C. Watt and X. C. Le, Talanta 58, 77 (2002).

36. P. R. Aranda, R. A. Gil, S. Moyano, I. E. De Vito and L. D. Martinez, Talanta 75, 307(2008).

37. M. Garrido, M. Di Nezio, A. Lista, M. Palomeque and B. F. Band, Anal. Chim. Act. 502, 173 (2004).

38. A. Afkhami, T. Madrakian and $H$. Siampour, Internatl. J. of Environm. and Anal. Chem. 86, 1165 (2006).

39. A. Shah, T. Kazi, J. Baig, H. Afridi, G. Kandhro, M. Arain, N. Kolachi and $\mathrm{S}$. Wadhwa, Food and Chem. Toxic. 48, 65 (2010). 